\title{
Balancing Atrocities and Forced Forgetting: Memory Laws as a Means of Social Control in Israel
}

\author{
Yifat Gutman (10) and Noam Tirosh
}

\begin{abstract}
This article examines memory laws as a new form of social control, demonstrating the significance of cultural memory to law and society scholarship. It focuses on two Israeli laws that seek to control public debate by giving voice to one marginalized group in order to silence another. The article presents two forms of such utilization of the law: forced forgetting and the balancing of atrocities. Forced forgetting validates the memory of one group of people over another group. Balancing atrocities equates victims, pitting the suffering of one group against that of another for the purpose of dismissing the former's claims for recognition and redress. The 2011 Nakba Law, an example of forced forgetting, dismisses the Palestinian minority's experience to amplify the memory of the Jewish majority, while the 2014 Jewish Nakba Law creates an analogy between Palestinian redress claims and those of the Mizrahi Jews in order to balance the atrocities that these groups suffered. We show that both forms of control have limitations that create gaps between legislation and implementation, yet their political-symbolic impact is much greater.
\end{abstract}

\section{INTRODUCTION}

Memory laws that fortify a certain ideal of the nation in light of public contestations of its past have been increasing since 2000 (Gutman 2016, 2019). Their legislators use memory to control what "truth" is and is not allowed in the public domain. By classifying certain interpretations of the past as deviant and stigmatizing, regulating and punishing the groups that express them, memory laws exert social control (Cohen 1985; Innes 2003; Dudai 2017). This article examines two memory laws in Israel as examples of such a use of the law; specifically, the Israeli laws demonstrate the use of two contemporary forms of political manipulation and social control that give voice to one group of citizens in order to control and silence another. We call these forms of social control "forced forgetting" and the "balancing of atrocities." The first form makes official the memory of one group in order to actively exclude other groups' memories from public debate on their shared past. The second creates analogies that equate victim groups, pitting the suffering of one group against the suffering of another for the purpose of dismissing the former group's claims for

Yifat Gutman is Senior Lecturer, Department of Sociology and Anthropology, Ben-Gurion University of the Negev, Israel. Email: gutmany@bgu.ac.il

Noam Tirosh is Lecturer, Department of Communication Studies, Ben-Gurion University of the Negev, Israel

An earlier version of this article was presented at the annual meeting of the American Sociological Association in New York in August 2019. We thank Ron Dudai and the reviewers for their helpful comments, Naaman Tal for research assistance, and the US-Israel Binational Science Foundation (Grant no. 2016354), as well as the Faculty of Humanities and Social Sciences at Ben-Gurion University, for funding this research. 
recognition and redress. These forms are not new, but their current utilization for reclassifying the past in order to define some interpretations, groups, and actions as deviant sheds light on contemporary legal forms of social control (Dudai 2017).

Outside of the legal sphere, balancing atrocities has become popular in the political speech of world leaders in recent years. President Donald Trump's reaction to the deadly violence against protesters who supported the removal of Confederate statues in Charlottesville, Virginia, in 2017 is one example, as he indicated that "there is blame on both sides" (Shear and Haberman 2017). Another example is Polish Prime Minister Mateusz Morawiecki's claim that both Poles and Jews collaborated with the Nazi occupation during the Second World War (Liphshiz 2018). Previously, the balancing of atrocities was theorized by Stanley Cohen (2001; see also Robinson 2003) as a form of state denial of known atrocities in order to avoid accountability for unjust treatment. Forced forgetting has been evident in political speech as well (Nyirubugara 2013, 50), but it is even more pertinent in memory laws, whereby the legislature uses the law to remember one group in order to actively forget another, utilizing sanctions that range from fines to incarceration (Gutman 2016).

Two Israeli laws dealing with the 1948 war provide good examples of both balancing atrocities and forced forgetting in order to control public debate. As Israel has been engaged in active and prolonged conflict with the Palestinians, the past at issue carries high stakes for the present and for any future conflict resolution. The Jewish majority and the Palestinian minority within Israel perceive the subject of the two laws-the 1948 war-very differently. The Jewish majority celebrates the country's formative War of Independence or War of Liberation as a national holiday on, or close to, 5 Iyar in the Hebrew calendar (which corresponds to May 14 in 1948), while the Palestinians mourn their extensive loss and displacement in the 1948 war, which they term al-Nakba (the catastrophe, in Arabic), on May 15. The 1948 war carried consequences for Jews who lived in Arab countries as well, for they faced sanctions by increasingly hostile Arab governments. Many of these Jews immigrated to Israel in the 1950s, where they experienced a consistent, long-lasting, and systematic marginalization by the founding elite who saw them as inherently inferior.

The 2011 Nakba Law addresses the Palestinian minority in Israel. ${ }^{1}$ It places budgetary sanctions on the commemoration of the Nakba during Israel's Independence Day celebration as well as three other types of public expression that are related to criticizing the nation-state. ${ }^{2}$ The law is an example of forced forgetting because it puts sanctions on Palestinian memory and, by so doing, forces the public to forget one group's experience (the Palestinian minority) in order to amplify the memory of another's (the Jewish majority). The 2014 Jewish Nakba Law, which is officially titled the Exit and Deportation of Jews from Arab Lands and Iran Day, addresses the Jews who immigrated from Arab countries—collectively called Mizrahi Jews ${ }^{3}$ — after the establishment of the

1. Budget Principles Law (Amendment \#40) (Reduction of financial allocations or support due to activity against the principles of the state) - 2011, popularly known as "the Nakba Law."

2. The law fines state-supported institutions that include any organization that receives funding from the state, including Jewish and Arab-Palestinian municipalities, universities, and cultural institutions.

3. Mizrahi means Oriental, signifying a distinct group that did not exist prior to the establishment of Israel-namely, Jews originating from the Balkans, North Africa, and the Middle East who immigrated to Israel primarily in the 1950 s. 
Jewish state in $1948 .{ }^{4}$ It creates a new commemoration day for their displacement and dispossession by Arab governments. The 2014 law is an example of balancing atrocities: it was framed by the legislators and state officials as commemorative, a correction to the historical injustice of excluding Mizrahi culture and experience from Israel's official memory and popular culture, which is mostly Ashkenazi (of Western origin) (Aderet 2015; Ababa 2015). Yet it also carries a political aim, which, as its popular name, the Jewish Nakba Law, suggests, creates an analogy between Palestinian displacement and redress claims from 1948 and those of the Mizrahi Jews who immigrated to Israel in the 1950s by dislocating the term "Nakba" from the Palestinian context to the Mizrahi context (Gabai 2014; Aderet 2015; Shragai 2016). As we will show, the law's analogy complements the Nakba Law; officiating the long overdue commemoration of Mizrahi experience and memory is meant to further hinder the commemoration of Palestinians.

The context for the legislation is rooted not in history but, rather, in contemporary political legitimacy or the lack thereof: the increasing disapproval, both domestically and internationally, of Israel's treatment of the Palestinians, with Israel's half-century-long occupation of the Palestinian Territories in the West Bank, its decade-long siege of Gaza, and the ongoing discrimination against Palestinian citizens in Israel (Robinson 2003). ${ }^{5}$ Since these two laws pertain to different groups of citizens in Israel and were legislated four years apart, they may seem to be unrelated. They also have opposite stated aims: the first limits the historical commemoration of a minority group, while the second officiates the memory of a different minority. However, examining the debates about the two laws and the context of their legislation, this study concludes that both laws serve the same political objective-namely, a combined effort to block domestic and international criticism against the discrimination of Palestinians and to gain legitimacy for the current state of conflict. Both laws are tied to the issue of Nakba memory, as their popular names indicate, which has been dialectically related to the self-perception of Israel's legitimacy (Jamal and Bsoul 2014). They are the only two Israeli laws that seek to control public debate over Israel's difficult past (VinitzkySeroussi 2002). ${ }^{6}$

This article shows the merit of merging memory studies with law and society scholarship. Viewing collective memory as an object of legislation and social control expands our understanding of the interrelations between law and society. Adding to the study of the cultural and symbolic dimensions of legislation, memory laws reveal more than the tensions of institutionalizing history and memory (Gutman 2016); they are a discursive area in which larger social issues are debated and political struggles over power and

4. Exit and Deportation of Jews from Arab Lands and Iran Day (Jewish Nakba Law), 2014.

5. Israel has changed its public diplomacy approach since the failure of Camp David's second peace summit in 2000 and the increasing domestic and international attention to the relevancy of the Nakba to today's state of the conflict (Oren and Bar-Tal 2007; Jamal and Bsoul 2014). Foregrounding the Nakba as a core issue in the Israeli-Palestinian conflict is perceived as a threat, to be fought with public relations campaigns in order to fortify Israel's narrative in what it perceived as a battleground on public consciousness (Jamal and Bsoul 2014).

6. According to Vinitzky-Seroussi $(2002,31)$ : "What constitutes a difficult past is an inherent moral trauma (Wagner-Pacifici and Schwartz 1991), disputes, tensions, and conflicts." By memory laws, we refer to the use of legislation in order to control public debate on the past in opposition to the principles of deliberative democracy and the freedom of speech (Gutman 2016). 
legitimacy take place (Löytömäki 2013). The study's contribution to considering law within the context of memory studies is threefold. First, connecting memory to social control is a line of research that has seldom been investigated (with notable exceptions, including Cohen 2001; Savelsberg and King 2005; Dudai 2017). Applying the lens of memory laws as social control to the Israeli case proposes a complementary explanation to the one provided by postcolonial studies of Israel's treatment of both the Mizrahi Jews and the Palestinians. While the two memory laws can be explained as another moment in Israel's continuous efforts as a settler colonialist regime to forcefully erase the cultural memory and disregard the dispossession of both Palestinians and the Jews of nonWestern origin (Kimmerling 1983; Shafir 1989; Shohat 1999), we show that institutions and ruling elites can use histories of displacement as a powerful tool of social control. However, as we will show, such utilization also carries contradictions and raises critiques that reveal the limits of state power.

The second contribution to memory studies is theorizing the central role of the law in shaping memory politics. Memory scholars focus on the construction of social memory in sites, acts, and narratives about the past, without realizing that such legislation is significant in shaping all three. Studying the legislation process of memory laws, in particular, reveals conflicts between competing perceptions of the past and struggles over inclusion and exclusion.

The third contribution joins a growing body of studies that demonstrate that forgetting is an active and intentional act of cultural memory construction (Zerubavel 2006; Assmann 2008; Connerton 2008, 2009; Vinitzky-Seroussi and Teeger 2010; Lemarchand 2011; Beiner 2013a, 2013b; Rieff 2016). We show that forgetting can be an intentional and increasingly popular act of controlling and silencing what and who may undermine dominant structures and efforts. In the Israeli case, Palestinian and Mizrahi experiences and counter-memories undermine the ongoing governmental effort to enforce a boundary separating Jews and Arabs, Israelis and Palestinians, which maintains the current state of conflict (Shohat 1999; Shenhav 2002). Moreover, the two laws combine forgetting and remembrance in a joint effort to control public debate about the shared past.

\section{THE PALESTINIAN NAKBA AND ISRAELI INDEPENDENCE}

The Nakba Law is Amendment no. 40 to the 2011 Budget Principles Law. ${ }^{7}$ It fines state-supported institutions that mark "Independence Day or the day of the establishment of the state as a day of mourning." It is the Palestinians, who account for approximately 20 percent of the population, who mourn on Israeli Independence Day. When Israelis celebrate the War of Independence as a miraculous victory against all odds that resulted in many casualties ( 1 percent of the population), Palestinians mark their loss in the 1948 war, which resulted in their massive displacement and dispossession, also known as al-Nakba. This is why the law intended to fine Palestinian commemoration is commonly known as "the Nakba Law." Israelis and Palestinians commemorate the

7. Budget Principles Law (Reduction of Financial Allocations or Support Due to Activity against the Principles of the State, 2011. 
war through opposite national narratives. In the dominant Zionist narrative, it is similar to David's miraculous victory over Goliath, who represents the Arab countries who fought alongside the Palestinians (Auron 2013). However, the Palestinian national narrative construes the events of 1948 as a tragedy inflicted on unequipped and unprepared peasants who were betrayed by both Britain and the Arab countries and subjected to an organized campaign of ethnic cleansing by Israeli military forces (Khalidi 1992; AbuSitta 2004).

From the 1950s onward, Israelis erased the Nakba from their national landscape, history textbooks, and their dominant collective memory (Shai 2007; Kadman 2008). Palestinians within and outside Israel have been struggling against this erasure in order to maintain their memories and identities as rooted in their villages and neighborhoods in pre-1948 Palestine (Abu-Lughod 2007; Bresheeth 2007; Davis 2007, 2011; Slyomovics 1998). A surge in Nakba commemoration emerged around its fiftieth anniversary in 1998 within and outside of Israel (Hill 2005). In the late 1970s, Jewish Israeli historians began to reexamine the Zionist narrative of the 1948 war in academic publications and in the pages of Haaretz (Ram 2007; Nets-Zehngut 2011). Instead of a miraculous victory against five Arab armies, as their predecessors had portrayed the war, they described it as an intentional campaign of a stronger and more organized Israeli military force to expel Palestinians (Flapan 1987; Morris 1987, 1988, 1990, 2007; Shlaim 1988, 1995; Pappé 1997a, 1997b, 1998; Ram 1998, 2006, 2007). In the 1990s, with the Oslo Peace Accords looming large, Jewish Israelis were more open to this revisionist discourse.

In the following decade, however, the atmosphere changed. The outbreak of the Al-Aqsa Intifada, a second upheaval in the Occupied Palestinian Territories in 2000, and the killing of twelve Palestinian citizens by Israeli border guards during protests within Israel, marked a new and violent chapter in the history of the conflict. In June 2002, the Israeli Cabinet ordered the erection of a separation barrier in the West Bank, which further exacerbated the physical separation between Israelis and Palestinians. Israelis and Palestinians further fortified their national narratives, pitting one national identity and history against the other (Auron 2013). However, scholarly, artistic, and activist knowledge about the Nakba continued to be produced by Jewish and Arab-Palestinian citizens in Israel, despite a growing backlash by the state and right-wing groups. The initial proposal of the Nakba Law in 2009 attempted to stop such knowledge production by criminalizing Nakba commemoration (Jamal and Bsoul 2014; Gutman 2017).

\section{THE MEMORY STRUGGLE OF JEWS WHO IMMIGRATED FROM ARAB COUNTRIES}

The term "Mizrahi" is a socially constructed identification that evolved in Israel in the 1950 s to describe the Jews who immigrated to Israel from the Middle East, Northern Africa, and the Balkans (Khazzoom 1999; Kimmerling 2001, 53-54). Indeed, ethnic tensions between Jews of different origins are among the most conspicuous aspects of the deeply divided Israeli society (Smooha 1993; Peled 2014). These tensions are a result of deep-seated structural and cultural differentiation between the 
Ashkenazim (plural of Ashkenazi) and the Mizrahim (plural of Mizrahi) and the latter's institutionalized discrimination by the former.

The Ashkenazim comprised the vast majority of the prestate Yishuv, which was the Jewish community in British Mandate Palestine. When Israel was established in 1948, the Yishuv prestate institutions were transformed overnight into Israeli government agencies. Jews of Western origin became the political and bureaucratic elites who managed the absorption of the Jews of non-Western origin who were immigrating to Israel during the 1950s. The absorbing institutions perceived the Mizrahi Jews as inherently inferior and as a group in need not only of modernization and assimilation into the hegemonic Ashkenazi culture but also of de-Arabization (Shenhav 2002; ShalomChetrit 2004). Living side by side with Muslims in their countries of origin "threatened to affect the coherence of the homogeneous Israeli nation and to blur the boundary between Jews and Arabs" (Shenhav 2002, 28). Therefore, Mizrahi Jews were asked to abandon the Arab world in which they grew up to join an Israeli collectivity that views Arab societies as the other. The Mizrahi past was deemed illegitimate in Israel (Dahan Kalev 1999).

In Israel, Mizrahi Jews experienced a consistent, long-lasting, and systematic marginalization that appears in almost every aspect of social mobility (Kimmerling 2001; Schejter 2007; Biton 2011; Dobrin 2015; Swirski, Konor-Atias and Zelingher 2015). A Mizrahi struggle movement emerged in the initial years of the state's founding (Shalom-Chetrit 2004). In 1959, a community member's arrest in the city of Haifa initiated violent clashes with the police, an event known today as the Wadi-Salib Riots (Smooha 2008; Weiss 2011). Twelve years later, Mizrahi activists from Jerusalem established the Israeli Black Panthers, a movement that vociferously tackled inequalities between Jews from Western and Eastern origins (Lubin 2016). In 1977, it was Mizrahi activism and popular support that helped the Israeli right wing win national elections for the first time (Filc 2009).

Currently, Mizrahi organizations focus primarily on cultural claims (Kizel 2014), including a systematic reformulation of the Israeli national narrative to include the forgotten history of Mizrahi Jews as equal "contributors to the Zionist ideology and mythology" (Schejter 2007, 929). This last demand is being slowly and partly answered by the right wing government, led by Benjamin Netanyahu since 2009. The government that ruled between 2015 and 2019 partially embraced the recommendations of an official committee that dealt with the empowerment of Mizrahi Jews within the Israeli educational system. The Biton Committee recommended the inclusion of Mizrahi history and literature in school colloquium and universities, through national media and online websites and portals, as well as the establishment of dedicated museums. Its predecessor government approved the Jewish Nakba Law, on June 23, 2014, which officially marks the suffering of Mizrahi Jews in their countries of origin in a national memorial day.

\section{LAW AND MEMORY, LAW AND FORGETTING}

Although the legal field plays a central role in struggles for collective memory, it has been under-theorized in the sociology of culture and memory. Scholars of memory 
tend to favor sites or acts of commemoration, such as memorials and museums, or the construction of narratives about the past. The law is central in shaping these sites, acts, and narratives, and, while it is often seen as institutionalizing state perceptions and interests (Savelsberg and King 2005), the process of legislation is a discursive arena in which contrasting perceptions of the past compete (albeit unequally) in an attempt to change people's views about present problems (Löytömäki 2013).

When we speak of society's memory, we refer to the construction of a "sense of past" (Confino 1997) by a social group in the present (Halbwachs [1925] 1992; Olick and Robbins 1998; Tirosh 2016) and not to the evaluation of what "actually happened." As such, memory processes are always contested and influenced by power relations and political struggles (Olick and Robbins 1998; Rowe, Wertsch, and Kosyaeva 2002; Tirosh 2016). While society's memory has been discussed by many scholars who have used different terms, we use the term "cultural memory" to describe the collective remembering of the past in an institutionalized, formalized, objectified, and crystallized form that eventually concretizes group identity (Assmann and Czaplicka 1995).

Often, as suggested earlier, national laws and the legal realm determine which events and narratives will be part of society's cultural memory and which narratives will be sidelined, ignored, or actively forgotten. A variety of national laws address the historical record or the shared perception of the past-for example, laws that control hate speech, establish the social calendar of memorial days, and create institutions that house the historical record and cultural memory, such as national museums and archives (Zerubavel 2003; Fronza 2006, 29; Savelsberg and King 2011; Tirosh and Schejter 2015). Such laws are usually shaped in line with the hegemonic perception of the national past and, in turn, help to fortify this perception while excluding national minorities (Gellner 1983; Anderson 2001; Nora 1996). For example, hate crime laws are shaped according to the dominant perception of certain atrocities in the nationstate's history and democratic tradition (see Savelsberg and King 2011), and laws that dedicate memorial days, ceremonies, and archives assist the educational system in disseminating these perceptions and memories in society (Durkheim [1912] 1995; Nora 1996; Zerubavel 2003). Memorial day laws, in particular, often include specific narratives about the nation and people and, by so doing, centralize and unify national commemoration around the majority while excluding national minorities (Gellner 1983; Anderson 2001; Nora 1996). In Israel, for example, significant events in the history of Palestinian citizens have always been excluded from memorial day laws or laws that establish memory institutions or archives. And, until 2014, Mizrahi memory was also almost absent from the national calendar.

Such omissions of minority or marginalized groups from the social calendar are not merely accidental — an unintended amnesia that results from giving preference to majority memory but a central part of memory. As Guy Beiner (2013a, 9) writes, as active and deliberate as remembrance, "forgetting is not the antithesis, but an integral component, of memory." Forgetfulness can be publicly advocated, especially in transitions to peace and democracy; in post-socialist Poland and post-Franco Spain, the public was asked by the new government to forget the violence in order to create stability and solidarity for the present and future (Boyd 2008; Connerton 2008; Beiner 2013b). In other cases, 
including the Israeli case, forgetting is enforced through the social calendar, the education system, and memory laws (Connerton 2008; Gutman 2017).

Yet memory laws take the omission of minority memory from the social calendar and public speech a step further, making them a form of social control. Unlike memorial day laws, memory laws center not on how the past will best be transmitted to the next generations but, rather, on how to control public debate on the past in the present (Gutman 2016). They are intended to protect a certain ideal of the nation from critical disputes on historical events, but, in practice, they determine who will be included in shaping the collective view of the past and who will be excluded (Gutman 2016; Koposov 2017; Uladzislau and Gliszczyńska-Grabias 2017). Memory laws institutionalize the silencing of particular groups more forcefully than memorial day laws: they target specific groups and criminalize their interpretations of the national past in order to exclude them from public debate (Gutman 2016).

While legal scholars tend to focus on the language of the law and memory scholars center on the sites and events resulting from the law, studying the interaction between law and memory through public debate in the process of legislation uncovers the social struggles over memory and the issues underlying these struggles, which the official outcome-the law or sites of memory-does not always reveal. The legislation process of memory laws, in particular, gives publicity to conflicts between different perceptions of the past that are expressed and compete for legitimacy.

\section{METHODOLOGY}

To explore the public debate around the legislation of the two memory laws, we analyzed news articles and the protocols of parliamentary committee meetings that discussed, wrote, and approved each of the laws in preparation for final approval by the Knesset plenum. To map the central views in public debate, we collected data from three of the most popular newspapers in Israel: Yedioth Ahronoth, Israel Hayom, and Haaretz (Schejter and Yemini 2015). In mapping the dominant political discourse, we consulted all parliamentary protocols that addressed the laws during the legislation process.

Media coverage of the 2011 Nakba Law was extensive, given the two-year process of legislation and the eight years that have passed since its approval. Reporting on the Nakba Law began after the preliminarily approval of its first draft in May 2009, surged around the approval of the final draft in March 2011, and rose again every May around Independence Day (our data collection terminated in June 2018). Overall, we found 302 articles (forty-seven in Yedioth Ahronoth, fifty-three in Israel Hayom, and 202 in Haaretz). The processes of legislation between 2009 and 2011 consisted of four parliamentary meetings of the Committee for Constitution, Law, and Justice. A meeting of the Treasury Committee followed the approval of the law to discuss its application regarding a specific cultural institution, the Tel-Aviv Cinematheque, on November 26, 2014. The parliamentary records do not reveal informal discussions and political dealings that form much of any legislative process, but protocols of parliamentary commissions serve as a stage for politicians and stakeholders to address certain social groups. 
We also searched for news regarding the 2014 law and the history of Jews in Arab countries or Iran between 2009 and 2018. Overall, we found forty articles (fifteen in Yedioth Ahronoth, fourteen in Israel Hayom, and eleven in Haaretz). Eleven were published before November 2014, and twenty-nine were published afterward. Five parliamentary meetings addressed the law between 2014 and 2016. Also included was the official statement of the Ministry of Foreign Affairs (MFA) on the approval of the law on June 24, 2014. We identified and contextualized data through multiple systematic readings of the research corpus (Hsieh and Shannon 2005; Kondracki, Wellman, and Amundson 2002) and used the tools of symbolic politics to analyze the public debate (Edelman 1985; Gusfield 1986). Symbolic politics analyzes approaches and statements regarding legislation and policy not solely as instrumental efforts to change reality or to solve a public policy problem but also as public statements that address values and norms of specific social groups (Gusfield 1986). As a sociopolitical lens focusing on legislation processes, symbolic politics focuses on tracing the meanings that such groups find in politics, based on their beliefs, expectations, and concerns. The laws in this case are a symbolic field in which different stakeholders debate in order to express wider norms and values (Dudai 2019).

Memory laws, in particular, are symbolic because they construct meaning as constitutive speech — they amend reality instead of merely describing it (Austin 1962). Memory laws mark who has the power to control public debate about the past. The law signals who has the upper hand in determining what perception of the past is legitimate and shapes the perception of institutions such as the education system, museums, monuments, memorial sites, and ceremonies. Such analysis does not center on the survey of all existing views or on their distribution but, rather, on the development of arguments by politicians and public figures that use preexisting cultural conflicts and commitments to address certain audiences.

\section{Forced Forgetting: The Nakba Law}

The Nakba Law was first proposed in 2008 by Knesset Member (KM) Alex Miller from the coalition's far-right Yisrael Beytenu Party ("Israel Is Our Home," in Hebrew). Miller's proposal carried a penalty of up to three years in prison to citizens who "mark Independence Day or the day of the establishment of the State of Israel as a day of mourning." 8 The proposal was preliminarily approved by the Ministerial Committee for Legislation on May 24, 2009, provoking enraged responses across the political spectrum in the media and an appeal by ministers from the Labor Party against the bill on May 25, 2009.

The proposal was eventually rejected and sent to the Committee for Constitution, Law, and Justice for revision. This yielded a less strict version that was approved by the Parliament in 2011. Instead of incarcerating individuals, the new version establishes fines on state-supported institutions that facilitate any of the following acts: (1) "mark Independence Day or the day of the establishment of the State of Israel as a day of

8. Draft Bill 458/18 Independence Day Law (Amendment - Prohibition on Marking Independence Day or the Day of the Establishment of the State of Israel as a Day of Mourning), 2009. See Glickman 2009. 
mourning;" (2) "reject Israel's existence as a Jewish and democratic state"; (3) "contain incitement to racism, violence, or terrorism; support armed struggle and terrorism by enemy or terror organizations against Israel"; or (4) "support acts of vandalism or physical desecration that dishonor the Israeli flag or the symbol of the state." Additionally, the authority to impose the fines is based on a ruling from the Ministry of Finance's legal counsel as well as on expert opinions from the Ministry of Justice (Hartman 2011). Thirty-seven KMs voted in favor of the Nakba Law, and twenty-five voted against, but sixty out of $120 \mathrm{KMs}$ avoided the decision by not showing up for the vote, including Prime Minister Benjamin Netanyahu. The majority of Jewish Israelis supported the law. Only 27 percent of Jewish Israelis supported the public commemoration of the Nakba in 2011, compared with 82 percent of Palestinian citizens in 2010 (Smooha 2013). However, prominent intellectuals, artists, and public figures condemned the law, including twenty laureates of the prestigious Israel Prize who published a public appeal before the bill was approved. ${ }^{9}$

In the parliamentary discussions leading up to the final version of the Nakba Law, various legal problems were raised by legal experts from the state attorney's office and by politicians from the opposition, both Jewish Israeli and Palestinian KMs. First, one of the central problems is that the law provides semi-legal authority to political actors to evaluate the impact of expressions on the public sphere in general as well as the power to enforce sanctions on the speakers for expressions that are themselves legal according to common legal standards (Ronen 2016). Second, the penalty does not fit the "crime," as the law states that public commemoration of the Nakba is not welcomed, whether it is funded by the state or not. Third, the penalty is applied to a budget that was originally distributed for one purpose-welfare, education, and other public services - in order to ban another, the undesired commemoration. As KM Isaac Herzog stated, the law would punish the poorest Palestinian citizens in Israel "because the head of the municipality decided to hold an event during Independence Day." Moreover, he noted that the bill "brings to the surface a topic that exists less and less in the Arab public and turns it into a spiteful issue." 10

Although the word "Nakba" was not included in the law, referring to acts of mourning during Independence Day points directly to a post-1948 tradition of Palestinian citizens of Israel, who visited their destroyed village lands on the national holiday because it was the only time during the year they were allowed to move freely throughout the country in the martial law period (1948-66) (Ben-Ze'ev 2004; Masalha 2005). In the early debate of the bill's revision in 2009, KM Miller tried to maintain the official stance that the Nakba bill does not target any specific group, but Miller's Israel Beiteinu colleague, Committee Head David Rotem, declared that the law indeed targets Palestinian citizens. ${ }^{11}$

9. Among the laureates were scholars (history, philosophy, education, physics, computer science, immunology, and geology), a former minister from the left-wing Meretz party, as well as cultural figures: architects, artists, authors, and actors (Lis 2011; Sofer 2011).

10. KM Isaac Herzog, Constitution, Law, and Justice Committee Protocol no. 362, March 14, 2011.

11. Knesset Member David Rotem, Constitution, Law, and Justice Committee Protocol no. 468, October 26, 2009. 


\section{Competing Perceptions of Democracy}

The changes made to soften the Nakba Law are telling of what is deemed legitimate and what is not in Israeli politics. The debate in Parliament and the media that accompanied the two-year legislation process featured two rival notions of democracy that were competing for public legitimacy: democracy as representing the interests of the ethno-national majority (the center-right coalition) versus democracy as the protection of minority rights (Palestinian KMs and the liberal-left camp). On the ethnonational side, remembering the Palestinian Nakba was deemed offensive to the Jewish majority. In the discussions in the Constitution, Law, and Justice Committee during the preparation of the softer version of the Nakba Law in 2011, Miller stated: "There is a limit to how democracy can be taken advantage of." According to Miller, the rationale behind the law remained the same despite the changes, protecting democracy from internal threats posed by the Palestinian minority. ${ }^{12}$ Upon the approval of the Nakba Law in the Knesset plenum, Rotem declared more bluntly that the law would reveal "how the far-left is ready to act against the state," referring to the liberal camp as a whole: "You worry about democracy, but in your way there won't be a state. This is a Jewish and democratic state, not a state of all its citizens." 13

The Israel Democracy Institute, an independent liberal research center, called the 2009 bill "anti-democratic, unconstitutional, and extremely detrimental to freedom of expression and to peaceful demonstration in Israel" (quoted in Kremnitzer and Konfino 2009). KM Isaac Herzog of the Labor Party had a similar reaction in a 2011 discussion in the parliamentary committee, arguing that "Israel's basic interest is freedom of expression and thought; this is what sustains it as a state."14 Since 2009, the critics have rejected the bill that they deem antidemocratic and harmful to free speech because it aims to silence a particular group of citizens, which stands in opposition to equal civic rights. On these grounds, the legal center for Palestinian minority rights in Israel, Adalah, and the Association for Civil Rights in Israel appealed to the Supreme Court, arguing that the law is unconstitutional. But the court used an American legal doctrine to determine that it cannot yet judge the law, as "[t]he questions that this law raises will only become clear with its implementation." 15 In 2015, a counter bill proposing a national Memorial Day for the Nakba was proposed by Palestinian KMs, but it was rejected in its early stages.

As in many cases of memory laws, the dispute between the two notions of democracy was not debated among equals, nor was the memory law a single tool in targeting a specific group (Gutman 2016). The Israeli right-wing coalition has been pushing its ethno-national agenda forward using not only the Nakba Law but also a series of discriminatory laws approved in 2011 that culminated in the Nationality Law in 2018. ${ }^{16}$ These laws fortified the privilege of the Jewish majority over the Palestinian minority

12. Knesset Member (KM) Alex Miller, Constitution, Law, and Justice Committee Protocol no.362, March 14, 2011.

13. Knesset Member David Rotem, Knesset plenum, March 22, 2011.

14. KM Isaac Herzog, Constitution, Law, and Justice Committee Protocol no. 362, March 14, 2011.

15. Adalah and ACRI on behalf of various appellants v. Ministry of Treasury and the Knesset, January 5, 2012, HCJ 3429/11, section 29.

16. Basic Law: Israel as the Nation-State of the Jewish People - 2018, July 19, 2018 (Nationality Law). 
and marked a tipping point in the already destabilized balance between an ethnonational (Jewish) and democratic state.

\section{Counterproductive Outcomes}

Despite the law's effort to silence Palestinian citizens and their supporters, the public debate also demonstrated the limits of this memory law (Gutman 2016). This was not only because a vocal elite opposed the law, generating media attention, including in the popular Yediot Achronot, which reported: "Nakba Law approved: 'Thought Police in Israel"' (Sofer 2011). Primarily, the debate disseminated the Nakba widely in Israeli society through the media coverage of the legislation process. As Haaretz contributor Odeh Bisharat (2011), a Palestinian citizen, stated, the law recognized that the Nakba exists. Instead of controlling and threatening marginalized voices, the debate also gave voice to memory activists that commemorated the Nakba and were marginal before the law's passing (Galili 2009). Despite the legislators' efforts to force the forgetting of the Nakba, the public debate revealed the limits of legitimacy for the exclusion of citizens' memories. However, the law pushed the limit a bit further by restricting the freedom of expression in service of the ethno-nationalist agenda of the right-wing coalition. The legal problems mentioned during the committee discussions were not solved either, but, in practice, they constrained the enforcement of the Nakba Law.

The Nakba Law has not yet been enforced, but the symbolic effect of memory laws is as, if not more, significant than their legal or educational outcomes (Dudai 2019; Gutman 2019). On the one hand, the legislation process of the law that was supposed to block the dissemination of Nakba memories ironically gave them visibility and publicity. In fact, in the years immediately following the law's inception, Nakba Day memorial ceremonies (on May 15) grew in and around Israeli university campuses, as have the right-wing protests against them. However, the threats and sanctions on Nakba commemoration have increased as well, as politicians informed by right-wing groups were called to sanction Nakba events, regardless of whether they take place on Independence Day. ${ }^{17}$ Moreover, the law is likely to have created a chilling effect on cultural, academic, and municipal institutions that self-censor the events they organize. As the law can be implemented at any moment, it has created an intimidating uncertainty regarding what may be an offense and what may not (Gutman 2019). Efforts to complement or amplify the Nakba Law were taken as well, including by Minister of Culture Miri Regev who made several attempts to use the Nakba Law to censor artistic and cultural production and institutions during 2016-19.

\section{Balancing Atrocities: The Jewish Nakba Law}

The 2014 Jewish Nakba Law creates a new Memorial Day on November 30 to mark "the Exit and Deportation of Jews from Arab Lands and Iran." It was framed by the legislators and state officials as being simply commemorative, but it carries a

17. Knesset Member (KM) Alex Miller, Treasury Committee, November 26, 2014. 
political aim that pertains to the Israeli-Palestinian conflict as well. The law assigns three ministerial tasks, two relating to commemoration and one that hints at the larger political role: (1) the Ministry of Senior Citizens, which has since changed its name to the Ministry of Social Equality, is responsible for organizing an official memorial ceremony; (2) the Ministry of Education is responsible for educational activities related to the day; and (3) the MFA is supposed to hold events, including at embassies abroad, to "increase the international consciousness of the Jewish refugees from Arab lands and Iran and of their right to compensation" (MFA 2014; emphasis added). The Knesset will also hold a special discussion to mark the day.

The task of commemoration is directed to the domestic realm, as indicated by its assignment to the ministries in charge of education and social equality, while the political aim is directed to the international arena, as assigning it to the MFA implies. The dual aim-cultural commemoration for internal recognition and political utilization of these groups' memory as a diplomacy tool—had different audiences: Mizrahi Jews and international public opinion, respectively. As we will show, the tasks were not equal in importance and visibility, yet their hierarchical order was masked in the public framing of the law as commemorative rather than political. This created tension between the representatives of the Mizrahi organizations and the state agents in parliamentary meetings leading up to the law's approval, as the former expressed concern that the commemorative aim was not effectively enshrined by the law and expressed doubt about the state's commitment to Mizrahi memory in the bill. ${ }^{18}$

Upon its approval (twenty-nine KMs voted in favor of the law and none voted against it), the law was introduced to the public primarily as a commemorative imperative, with its political objective being less apparent in mainstream media. The annual ceremonies in 2014 through 2017 emphasized the long-overdue inclusion of Mizrahi history in the artistic program, official memory practices (a moment of silence, the Jewish memorial prayer, and survivor testimonies), and speeches by public officials (President Reuven Rivlin and Prime Minister Netanyahu in 2014; Minister Gila Gamliel in 2015-17), a frame that was also evident in media reports of the ceremonies. ${ }^{19}$ Despite the emphasis on commemoration, we argue that the political aim and the international political context, rather than the internal process of recognition of Mizrahi memory, created the momentum for the approval of the bill. ${ }^{20}$

18. Meir Kahlon, Zvi Gabai, Levana Zamir, and Linda Menuchin, Education, Culture, and Sports Committee, June 9, 2014.

19. If the political aim was mentioned, for example in covering Prime Minister Netanyahu's speech in the first ceremony in Israel Hayom (2014), it took less space and appeared at the end of the coverage. Those who emphasized the political aim around the memorial day's date were mostly right-wing columnists (Yemini 2015; Amroussi 2016), and Zvi Gabai (2014, 2015, 2017). One exception was a report in Israel Hayom days before the 2017 ceremony, which centered on the Ministry of Foreign Affairs' (MFA) task of "presenting the narrative of the exit and deportation of Jews from Arab countries and Iran around the world, both to address [Israel's] public image and a commitment to historical justice," as cited by a MFA official (November 27, 2017).

20. The initiators of the law failed to pass a bill that integrates the history of Mizrahi Jews into Israel's national narrative in the previous two parliaments. While grateful that they finally succeeded in advancing their bill to its final stage of approval in 2014, Shimon Ohayon and Nissim Zeev also raised concerns about the effective implementation of its commemorative task. Ohayon and Zeev, Protocol of the Education, Culture, and Sports Committee, June 9, 2014. 
The first commemoration ceremony was held in November 2014 at the presidential residence and organized by then minister for senior citizens, Uri Auerbach. The media reports followed the official statements of the ministries involved and the speeches featured in the ceremony. For example, Yedioth Ahronoth reported that the date chosen for the new annual commemoration-one day after the historical United Nations approval of the Partition Plan of Palestine on November 29, 1947 (17 Kislev, in the Hebrew calendar $)^{21}$ - is significant since it marked the beginning of the oppression of Jewish citizens by Arab governments, as Prime Minister Netanyahu stated in the first ceremony (Gabai 2014; Israel Hayom 2014). Moreover, tying the dispossession and displacement of Mizrahi Jews to the 1948 War of Independence, rather than viewing their contribution as one that begins at the time of immigration in the 1950s, casts them as active participants in Israel's founding moment through public acknowledgment of their sacrifice for state independence (as Gila Gamliel stated in the 2015 ceremony). It also brings them to a more equal ground with Ashkenazi-centered leadership and institutions of pre-state settlement and the 1948 War of Independence. However, underlying this choice of date is another link between Mizrahi Jews and Palestinian refugees, which enables us to view them as victims of the same event, the 1948 war and the establishment of Israel (Shenhav 2003). This link was not mentioned in media reports of the ceremonies but has been mentioned in media reports by national security reporters in other contexts.

The framing of the law as primarily commemorative addressed the misrecognition claims of Mizrahi audiences within Israel. At the 2015 ceremony, Minister for Social Equality Gila Gamliel emphasized the law's historical bridging of the gap in knowledge about the history and heritage of Mizrahi Jews (Yedioth Ahronoth 2015; see also Aderet 2015). This gap was the main issue raised by the organizations of immigrants from Arab countries in the meeting of the parliamentary Education, Culture, and Sports Committee, which prepared the bill for final approval in Parliament. ${ }^{22}$ Representatives of the Jewish organizations who immigrated to Israel from Iraq, Egypt, and Libya, as well as international Jewish organizations, also stated their long and frustrating history of advocacy for the state's acknowledgment of the history and heritage of their communities. After the bill was approved by the committee, Meir Kahlon, head of the World Organization of Libyan Jews, opened on a non-celebratory note: "It hurts me very much that we had to beg [the state] and ask to be partners. Constantly having to ask for favors, I am glad there is a decision now. We are talking about creating a balance in the education system; ... these communities that came from Arab countries ... are not a third or fourth party, but a very big part of this state. They therefore deserve that their suffering will be addressed ... in a way that would make their children proud." 23

The representative of other immigrant organizations expressed similarly mixed feelings regarding the new law due to their concern that the law was too limited and nonobligatory in comparison to the law that concerns the redress and history of

21. The partition plan dividing the area formerly ruled by the British Mandate into two national territories, one Jewish, one Arab, which led to the Declaration of the State of Israel.

22. Education, Culture, and Sports Committee Protocol, June 9, 2014)

23. Meir Kahlon, Education, Culture, and Sports Committee Protocol, June 9, 2014. 
European Jews who perished in the Holocaust. ${ }^{24}$ They were afraid that the law would not be implemented by the education system. Zvi Gabai, who represented the Jews who had immigrated from Iraq, stated: "Don't do this as if you are doing a favor. I feel humiliated that I have to beg and ask that [the law] would be enacted and enforced. ... There are tens of laws that are useless; they have no meaning. If there is no will to the Minister of Education, and the Minister of Foreign Affairs, and the Minister for Senior Citizens and so on." Being a former MFA official himself, he later excluded the MFA from his statement. ${ }^{25}$

Other Mizrahi organization representatives, such as Levana Zamir (International Association of Jews from Egypt) and Linda Menuchin (Justice for Jews from Arab Countries), said that the law covered what had already been done in practice by Mizrahi organizations, which plan cultural and educational events. Menuchin also referred to the experience of Jews from Arab countries as "my Nakba" yet kept to the framework of commemorating the heritage of "fifty per cent of the population." 26 These calls to effectively dedicate the law to commemorate Mizrahi Jews were joined by an expert view, that of Lilly Halperin, who attended the meeting. She called for letting the memory of Mizrahi Jews to stand on its own and not in relation to the conflict: "Give it all the respect. It doesn't have to be a condition or part of the Israeli-Arab conflict. I think this [link with the conflict] has been something that delayed the commemoration of Mizrahi Jews ... it takes you to places of developing deep political calculations." 27 The meeting was closed with the statement by the committee chair, Amram Mitzna, who is Mizrahi as well, that the law is "doing historical justice to

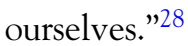

\section{Jewish Property and Palestinian Redress}

Both the 2014 Jewish Nakba Law and the 2011 Nakba Law aimed to block the dissemination of Palestinian claims. As stated by different stakeholders, advocates of the law, and right-wing columnists, the 2014 law officiated the commemoration of Mizrahi displacement and dispossession in order to control and defend against accountability for Palestinian displacement and dispossession (Israel Hayom 2015; see also Regev 2010; Bergman 2013; Gabai 2014, 2017; Yemini 2015; Amroussi 2016; Shragai 2016). These speakers who support the balancing atrocities aim of the 2014 law utilized terms

24. Zvi Gabai, Levana Zamir, and Linda Menuchin, Education, Culture, and Sports Committee Protocol, June 9, 2014. This narrative, which was expressed by Minister Gamliel in the official ceremony in 2015 (Israel Hayom 2015), hints at the material and symbolic inferiority of Mizrahi Jews in Israel, as Holocaust survivors have received material compensation from Germany and subsidies from Israel. Symbolically, Israel's treatment of its Holocaust survivors has changed over the years, from silencing their experience until the Eichmann trial in 1961 (Segev 1993; but see Shapira 1998 for a different view), to sanctifying survivors' memories in Israel's victimization and security narratives (Zertal 2005). Israel's incorporation of Holocaust memory has also been seen by some as a defense against accountability (Said 2000) or even as a justification for its ongoing treatment of Palestinians (Moses 2011).

25. Zvi Gabai, Education, Culture, and Sports Committee Protocol, June 9, 2014

26. Zvi Gabai, Levana Zamir, and Linda Menuchin, Education, Culture, and Sports Committee Protocol, June 9, 2014.

27. Lilly Halperin, Education, Culture, and Sports Committee Protocol, June 9, 2014.

28. Amram Mitzna, Education, Culture, and Sports Committee Protocol, June 9, 2014. 
identified with the Palestinian struggle for recognition and redress-refugees, ethnic cleansing, and Nakba - that were not used earlier in reference to Mizrahi Jews. While the law focuses on commemoration, the political project behind it uses the legislation as a form of balancing atrocities to gain international legitimacy (Israel Hayom 2015); it pits the memory and redress claims of Mizrahi Jews for their dispossession and displacement by Arab governments in the 1950s against the memory and claims of Palestinians' dispossession and displacement by Israeli military forces and the Jewish state in 1948.

While the law's framing as primarily commemorative appears to be a solution for a domestic dispute, looking at the history of Israel's treatment of Mizrahi memory and claims indicates that it is, in fact, part of a larger project to document and assess the dispossession and other damages that Mizrahi Jews suffered under Arab governments that were responding to the success of Zionism (Regev 2010; Bergman 2013; Shragai 2016). The project had two arms: first, a semi-covert operation, led by former Mossad official General Uzi Arad since 2007 to document the possessions left by immigrating Jews in Arab countries and estimate their total value in preparation for an international property claim (Regev 2010; Bergman 2013); second, public memory programs organized primarily by the Office for Senior Citizens in the last decades that encourage Mizrahi Jews to share their life stories, focusing on life in Arab countries and the property left behind (Regev 2010; Barkan 2013). In both public and secret operations, the MFA has been a central actor in the effort to document dispossessed property and draw attention to Jewish refugees in the international arena.

Efforts to balance atrocities by highlighting Jewish refugee narratives began a few years prior to the law in a political context. In 2009, after his first visit to Washington, Prime Minister Netanyahu directed General Arad, who was then the head of the National Security Council to start preparing for the renewal of negotiations with the Palestinians (Ravid 2012). Arad, who had been dealing with assessing Jewish property in Arab lands since 2006, had assembled a special team to prepare Israel's official stance on the issue, which submitted its report in May 2011 (Ravid 2012). The report states that Israel's interest was to link "the tragedy of the Jewish refugees" with the "issue" of the Palestinian refugees in a joined discussion of a permanent settlement with the Palestinians (Ibid.). The report stated that this link would be used for deterrence and that it would downplay Palestinian claims or at least limit the focus on this issue. The government accepted the report's recommendation to include "the problem of Jewish refugees from Arab countries" as a core issue in the negotiation on a permanent settlement with the Palestinians (Ravid 2012). Consequently, Vice Minister of Foreign Affairs Danny Ayalon launched a campaign in 2012 that included video clips of Mizrahi Jews' testimonies on the pogroms they suffered before immigrating to Israel. Each clip ended with the sentence: "I too am a refugee." 29

In 2013, General Arad stated that the project was meant first and foremost to fight the rise of international legitimacy for Palestinian claims by balancing and countering

29. See “I Am a Refugee," Facebook, https://www.facebook.com/imarefugee. Already in 2010, the Office for Senior Citizens launched a project to document the memories and lost property of Mizrahi Jews (Regev 2010), and, in May 2013, it enhanced its efforts with a public relations campaign and a call center that will receive and document the stories (Barkan 2013). 
the redress claims of Palestinian refugees against Israel (Bergman 2013). "Our goal was to create a situation of complete equation," he said in an interview in the popular weekend supplement of Yediot Achronot: "When peace talks on a permanent settlement will renew, Israel would state the [Jewish claims] issue through linking it to the [Palestinian] refugees issue on each of its dimensions. One refugee's law is another refugee's law. For each dollar for the Palestinians, a similar dollar will be given to the Jewish refugees. All based on a symmetrical and simultaneous basis. Half goes to Jews and half to the Arabs, without preference to any side" (quoted in Bergman 2013).

In assessing the value of the property for redress, General Arad's team demanded that Israel receive additional compensation for its investment in integrating the Jews from Arab countries (Ravid 2012; Bergman 2013). This claim joins the transformation of Mizrahi Jews from enthusiast "ascenders" to Israel to refugees. It presents Mizrahi Jews not only as victims without agency or Zionist conviction but also as marginalized newcomers in need of modernization, assimilation, and integration, which continues the state norms and beliefs dating to the 1950s. This narrative undermined a major trope of the Zionist ideology: the longing of diaspora Jews to return to their biblical homeland. Instead of "ascending," this narrative presented Mizrahi Jews as refugees escaping abusive governments (Ravid 2012). While fitting another Zionist trope-that Israel is the only safe place for Jews-Mizrahi Jews were left without agency as helpless refugees instead of Zionist enthusiasts (Shenhav 2003; Bisharat 2012; Shalev 2016; see also Danny Ayalon, cited in Ravid 2012). General Arad's statement and the special team report demonstrate how Mizrahi experience and memory were utilized for national interests internationally but were not acknowledged in Israel. This also explains why the commemorative aim of the 2014 law was therefore secondary to its political aim.

Organizations that represent Mizrahi Jews in Israel have been aware of the state's priority and its efforts to document Jewish property in order to deduct their redress claims from Palestinian redress claims. They have expressed prolonged disappointment with the state's failure to advance their claims for redress from Arab leaders until the right political momentum is reached (Bergman 2013). "I am unwilling to hear the word deduction ever again," said Levana Zamir, head of the organization of Egyptian Jews in Israel in a 2013 interview (quoted in Bergman 2013). Since the Labor government in 1950, "every Israeli government wants to deduct the value of my father's property with some Arab from Jaffa or Ramle. I hereby declare that we will not be part of this thing. ... there is a limit to our abuse. ... Khalass (enough in Arabic), it's over," she declared (Bergman 2013, n.p.).

Until the issue became a national foreign policy matter, Israel did not deal with individual redress claims of Jews against Arab governments. Even when the opportunity presented itself - in the face of the confiscation of Iraqi Jewish possessions in the 1950s or later in the 1979 Peace Treaty with Egypt, for example-redress claims were framed by the state as a strategic asset that should be saved for future occasions. Foreign Minister Moshe Sharet, whom Zamir mentioned, addressed the confiscation of property from Iraqi Jews for the first time in September 1949, in response to a call to assist these Jews in their time of crisis. He framed the issue as a foreign policy matter that needed to be reserved for a future peace agreement with Iraq and rejected a proposal to deduct Iraqi Jewish property from Palestinian possessions left after their displacement (Shenhav 1999, 612-13). The link between Jewish and Palestinian dispossession only 
developed later into "an ideological thesis and official practice of the Israeli government” (613). However, like any foreign affairs policy, this link was advanced or delayed according to the changing occurrences of the conflict and international opportunities to resolve it. If, in 2009, General Arad and Prime Minister Netanyahu were preparing for peace talks on a permanent settlement with the Palestinians, the years that followed only fortified the refusal of Netanyahu's government to engage in conflict resolution, especially in response to the American President Barack Obama's efforts.

Internationally, the issue of Jewish refugees from Arab countries has received attention only recently, primarily as a result of active efforts by Israel and international organizations like the World Organization of Jews from Arab Countries, Justice for Jews from Arab Countries, and the World Jewish Congress (Adelman and Barkan 2011, 185). The aim of these efforts was to counter Palestinian redress and return claims using a narrative that created a parallel between Palestinian refugees and Jewish refugees (Shenhav 2003; Adelman and Barkan 2011). In July 2000, American President Bill Clinton launched a campaign to acknowledge Jews from Arab countries as refugees when he disclosed in an interview that such an agreement was discussed at the Camp David Summit (Shenhav 2003). Behind the idea for the campaign were Prime Minister Netanyahu's former adviser for Diaspora affairs and his colleagues, along with delegates from Jewish organizations. The goal of the umbrella organization of the campaign for Jewish refugees, Justice for Jews from Arab Countries, was similar to previous efforts - namely, to stop Palestinians' "right of return" and reduce Israel's liability to compensate them for dispossessed property from 1948. Yet the campaign did not succeed in attracting reactions or political statements from any major Israeli politician (Shenhav 2003). In Israel, the MFA continued to develop the idea, and, in 2009, the joint effort with the National Security Council began.

\section{Reproducing the Categories}

Although the term "Jewish Nakba" does not appear in the 2014 law, it is used repeatedly by its advocates and right-wing columnists to create an analogy between Mizrahi and Palestinian claims (Gabai 2014, 2015; Yemini 2015; Amroussi 2016). ${ }^{30}$ One of these advocates is the former ambassador and Mizrahi activist Zvi Gabai, who may have coined the term in a 2012 op-ed piece that he published in Haaretz and that he used in consequent op-eds in 2014-17 on or around November 30, the new memorial day. Gabai was born in Iraq, immigrated to Israel as a child. After he retired from the MFA, he became active in advancing the issue of Jewish property as well as in organizations of Jews who immigrated from Iraq. In his op-eds, Gabai explained what the law is for and argued that it is unreasonable to address the tragedy of the Palestinian refugees while neglecting the loss suffered by Jewish refugees (see, for example, Gabai 2014, 2017). Gabai uses the term "Jewish refugees," which General Arad's team proposed in 2011, after they found that "in the worldwide discourse, when

30. Another duplication can be found in describing the Nakba as "the Palestinian Holocaust," for example, in the Palestinian National Council's statement on Nakba Day 2015 (May 15, 2015, wafa.ps). On linking the Holocaust and the Nakba in the context of the ongoing conflict, see Bashir and Goldberg 2018. 
refugees and redress are discussed, they [the Palestinians] managed to take over the whole issue in consciousness-raising. In our work on the topic I wanted to do justice with the Jewish refugees as well" (General Arad, quoted in Bergman 2013).

On Nakba Day in 2015, in an op-ed entitled "And What About Our Nakba?" Gabai (2015) addresses the comparison of Jewish and Palestinian refugees by using similar categories. First, he conflates the domestic exclusion of Mizrahi Jews with the Palestinian international struggle for legitimacy in the same paragraph: "What are Israelis who migrated from Arab countries supposed to tell their children about their history? Neglecting the history of Jews of Arab countries and ignoring their heritage made their tragedy blurred and under-represented in the world. Unlike them, the Palestinians have successfully presented their narrative and gained international sympathy." Second, he provides demographic data as evidence that Jews have been ethnically cleansed, which is how Palestinians define the Nakba. Yet he assigns the term "history" to the Jewish refugees and "narrative" to the Palestinian refugees to distinguish between what he deems to be fact-based history versus an interpretation of the past. Gabai's equation of atrocities turns the power relations upside down to mark Jews of Arab countries as misrecognized and Palestinian refugees as recognized and sympathized.

Jews who immigrated from Arab countries were first called "refugees" by Yaakov Meron, head of the Justice Ministry's Arab legal affairs department and a member of the World Organization of Jews from Arab Countries (Shenhav 2003). In an effort to equate Mizrahi Jews and Arab Palestinians as victims of the 1948 war, Meron not only balanced atrocities but also claimed that Palestinian leaders encouraged the expulsion of Jews from Arab countries, and he termed this policy "ethnic cleansing" (Shenhav 2003). Like Meron, Gabai and right-wing columnists hold Palestinians responsible for the oppression of Jews in Arab countries: "Israel needs international recognition of the huge human tragedy that Arab-Palestinians, actively assisted by the Arab countries, have caused" (Gabai 2015; see also Yemini 2015; Amroussi 2016). Blaming the victim for the same crime that one is called to take responsibility for is based on the reproduction and dislocation of categories used by the victim. The aim is to redirect the arrow of accountability and redress from Israel to the Palestinians. Ironically, reproducing the Nakba also attests to its historical existence, which was, for many years, denied.

\section{DISCUSSION AND CONCLUSION}

Our findings show how memory laws have been used as a form of social control in Israel. They not only indicate that remembering and forgetting are similarly utilized for specific political purposes but also show how new forms of reclassifying the past define some interpretations, groups, and actions as deviant in the context of populist and nationalist exclusion. These forms—-forced forgetting and balancing atrocities—are evident in the two laws studied. The 2011 Nakba Law sanction state-funded institutions that commemorate the Palestinian Nakba during Israel's Independence Day celebration (and other related acts and expressions) and, by doing so, fortifies the memory of the Jewish majority and forces the forgetting of the Palestinian minority. The 2014 Jewish Nakba Law was based on the logic of balancing atrocities, creating analogies between victim groups in order to acknowledge one and dismiss the other. The law created two 
such analogies between Mizrahi Jews and Ashkenazi Jews and between Mizrahi Jews and Arab Palestinians.

Although most media attention and parliamentary meetings were dedicated to the commemorative aim of the Jewish Nakba Law, we have shown that the political aim of the law was the true priority of the state-namely, to gain legitimacy internationally at the time of legislation. Taken together, the use of these forms for antidemocratic exclusion of minority memories and redress claims sheds light on Israel's continuous process of democratic decline that peaked in 2018, with the legislation of the Nationality Law, ${ }^{31}$ which defines Israel as a state of its Jewish majority. In this concluding section, we discuss the consequences of these findings to other and future cases and show how these concepts lend themselves to generalization.

Forced forgetting carries symbolic and political significance that extends beyond its effective implementation. The political impact of the Jewish Nakba Law was the legislators' power to use memory as a tool for social control, to openly silence and exclude a group of citizens (Gutman 2019). In Israel, the law also performed the right-wing coalition's task of pushing majority memory on the expanse of democratic equality. ${ }^{32}$ The form of balancing atrocities consists of three central elements that carried particular consequences in the Israeli case study. First, balancing atrocities reverses established meanings and creates new boundary distinctions between groups in society. In Israel, the equation of Mizrahi and Ashkenazi Jews reverses the distinctions made by the double process of assimilation that the Mizrahi Jews went through in Israel. This process included, first, assimilation to European-oriented Hebrew culture that dominated Israeli society and, second, de-Arabization to shed any association with cultures that were perceived as the ultimate other of Zionism. In the 2014 Jewish Nakba Law, both processes of integration were reversed; acknowledging Mizrahi culture and history as equal to Ashkenazi culture reverses the forced assimilation and differentiation between these cultures, and equating Mizrahi Jews and Palestinians reverses the de-Arabization process by writing the experience and memory of living in an Arab country back into Mizrahi identity.

However, such reversals and new boundary distinctions are limited as inclusionary mechanisms as they are geared to offer change, such as the inclusion of one marginalized group, as a means for a specific political purpose, such as further excluding another group. In Israel, both analogies_-between Mizrahi and Ashkenazi Jews and between Mizrahi Jews and Palestinian citizens_-reinstated the opposition between Jews and Arabs. They have done so by tying Mizrahi experience to mainstream Zionist history through the trope of the diasporic communities' sacrifice for the nation, which is one of the main justifications for the establishment of a Jewish state. However, the possibility of solidarity between Jewish and Arab neighbors in the diaspora is restricted in this depiction, which focuses on ethno-national rivalry and victimization. The hyphenated identity of an Arab-Jew that draws a connection between these cultures continues to be invalid in contemporary Israeli society, as it has been previously (Shenhav 2003).

31. The Nationality Law states that the land of Israel is the historical homeland of the Jewish people, Jerusalem is its capital, and Hebrew is the state's language.

32. Miller and Rotem in the Constitution, Law, and Justice Committee meeting, March 14, 2011). 
Second, balancing atrocities carries contradictory outcomes. On the one hand, equalizing Mizrahi and Ashkenazi Jews includes Mizrahi Jews in Israeli society. On the other hand, using Mizrahi Jews' diasporic experiences instrumentally, for the purpose of invalidating Palestinian claims, also invalidates Mizrahi experience and claims, deepening state neglect. This is the reason that Mizrahi organizations criticized the 2014 Jewish Nakba Law. In this process of equalizing Mizrahi Jews and Arab Palestinians, one episode of Mizrahi experience is remembered, while others are forgotten, particularly the dual assimilation process that marginalized Mizrahi Jews and which carries consequences to this day, as well as the ideological Zionist motivations behind their immigration to Israel. In order to fit the category of refugee, they are transformed from active social actors to powerless victims (Shenhav 2003; Biton 2011). Representatives of the Mizrahi Jews raised doubts that their memory and property claims against Arab governments will indeed be heard instead of utilized as a national asset for political interests.

Third, balancing atrocities is often conducted through dislocating common terms and categories used by one group and applying it to another. An extreme example is the earlier-mentioned dislocation of the category of "collaborators" with the Nazi occupiers by Prime Minister Morawiecki from Poles to Jews, suggesting that the victims of the Holocaust were also perpetrators of its crimes. In Israel, the analogy is between victim groups of dissimilar events that took place in different times in an attempt to connect them to the same root cause-the 1948 war. Legislators describe the experience of Mizrahi Jews in terms taken from Palestinian collective memory and redress claims, adopting the categories of refugee and ethnic cleansing and even appropriating the term "Nakba" from its Palestinian origin and Arabic language. This shows that silencing can be actively and forcefully enacted either through the omission of names and terms-the Nakba Law does not mention the term "Nakba" in its efforts to sanction Palestinian commemoration-or through co-opting and dislocating terms as in the Jewish Nakba Law.

While, in other cases of intercommunal conflict, efforts to balance atrocities were strategically perused after forced forgetting did not work (Minow 2002), in the Israeli case, we point to a complementary relationship between the two forms as demonstrated by the laws we have studied. The laws complement each other as two arms in the same struggle for social control and legitimacy. One arm attempted to control the internal debate about 1948 through forced forgetting, while the other tried to reduce Israel's accountability for the conflict in the international arena through balancing atrocities. However, gaps between the aims of the legislators and effective implementation of the Israeli laws demonstrated the limits of these forms. As mentioned, the Nakba Law has not yet been implemented, and the Jewish Nakba Law has not yet reached great attention and reception. Such gaps stem both from general and concrete reasons. Generally, gaps stem from the internal contradiction of memory laws - using the law, which is supposed to be a tool for enshrining equal rights in a democracy, for an antidemocratic aim: officiating one interpretation of the past and excluding other interpretations by posing sanctions on those who publicly express them (Gutman 2016). Moreover, memory laws give publicity to the same past that they seek to silence and control: in Israel, the 2011 Nakba Law widely popularized the past that it sought to silence, and the 2014 Jewish Nakba Law acknowledged the past it sought to delegitimate (the Nakba). 
These gaps may seem to indicate a failure in using memory laws for social control, yet the symbolic meaning attached to the act of legislation is more significant than their implementation in practice. Dudai (2019) demonstrated this idea regarding another unexercised Israeli sanction - the death penalty for terrorists - which has channeled both frustration and self-legitimating restraint in Israeli society. As mentioned, the symbolic effect of the Nakba Law goes beyond the intimidating uncertainty of a vague definition of the "crime" and a disproportional penalty. In addition to the general consequences discussed, scholars applying forced forgetting and balancing atrocities to future cases can also benefit from finding other strategic relationships between the two forms of control and from expanding the economic aspects of reparations that both forms have been used to preempt. In the Israeli case, the economic traits remained in the background due to the changing prospective for conflict resolution, yet, in other cases, forced forgetting and balancing atrocities carry both political and material implications.

\section{REFERENCES}

Ababa, Dani Adino. 2015. "Remembering the Deportation of the Jews of Arab Counties." Yedioth Ahronoth, December 1.

Abu-Lughod, Lila. 2007. "Return to Half-Ruins: Memory, Postmemory, and Living History in Palestine." In Nakba: Palestine, 1948, and the Claims of Memory, edited by Ahmad H. Sa'di and Lila Abu-Lughod, 77-106. New York: Columbia University Press.

Abu-Sitta, Salman H. 2004. Atlas of Palestine 1948. London: Palestine Land Society.

Adelman, Howard, and Elazar Barkan. 2011. No Return, No Refuge. New York: Columbia University Press.

Aderet, Ofer. 2015. "One of the Commemoration Day Law Aims: Creating a Parallel with the Palestinian Refugees." Haaretz, November 30 (in Hebrew).

Amroussi, Emilie. 2016. "The Devastating Pain of the Silent Fathers." Israel Hayom, December 9.

Anderson, Benedict. 2001. Imagined Communities. 2nd ed. London: Verson.

Assmann, Aleida. 2008. "Transformations between History and Memory." Social Research: An International Quarterly 75, no. 1: 49-72.

Assmann Jan, and John Czaplicka. 1995. "Collective Memory and Cultural Identity." New German Critique 65: 125-33.

Auron, Yair. 2013. The Holocaust, the Rebirth and the Nakba. Tel Aviv: Resling.

Austin, John L. 1962. How to Do Things with Words. Edited by J. O. Urmson and Marina Sbisá. Cambridge, MA: Harvard University Press.

Barkan, Noam. 2013. "To Preserve the Memories." Yediot Achronot, May 19.

Bashir, Bashir, and Amos Goldberg, eds. 2018. The Holocaust and the Nakba: A New Grammar of Trauma and History. New York: Columbia University Press.

Beiner, Guy. 2013a. "Disremembering 1798? An Archaeology of Social Forgetting and Remembrance in Ulster." History $\mathcal{E}$ Memory 25, no. 1: 9-50.

—. 2013b. "Forgetting to Remember Orr: Death and Ambiguous Remembrance in Modern Ireland." In Death and Dying in Ireland, Britain, and Europe: Historical Perspectives, edited by James Kelly and Mary Ann Lyons, 171-202. Sallins, Ireland: Irish Academic Press.

Ben-Ze'ev, Efrat. 2004. "The Politics of Taste and Smell: Palestinian Rites of Return." In The Politics of Food, edited by Marianne Lien and Brigitte Nerlich, 141-59. Oxford: Berg.

Bergman, Ronen. 2013. "This Was My House." Yediot Achronot Weekend Supplement, July 12 (in Hebrew).

Bisharat, Odeh, 2011. "The Palestinian Narrative Won." Haaretz, March 24 (in Hebrew).

—. 2012. "Return or Redress to the Jewish Refugees." Haaretz, October 9 (in Hebrew). 
Biton, Yifat. 2011. "On the Nature of Discrimination: The Mizrahim in Israel between the Overt and the Covert." Masai Mishpat 4: 75-92 (in Hebrew).

Boyd, Carolyn P. 2008. "The Politics of History and Memory in Democratic Spain." Annals of the American Academy of Political and Social Science 617: 133-48.

Cohen, Stanley. 1985. Visions of Social Control: Crime, Punishment and Classification. Cambridge, UK: Polity Press.

2001. States of Denial: Knowing about Atrocities and Suffering. Cambridge, UK: Polity Press.

Bresheeth, Haim. 2007. "The Continuity of Trauma and Struggle: Recent Cinematic Representations of the Nakba." In Nakba: Palestine, 1948, and the Claims of Memory, edited by Ahmad H. Sa'di and Lila Abu-Lughod, 161-87. New York: Columbia University Press.

Confino, Alon. 1997. "Collective Memory and Cultural History: Problems of Method." American Historical Review 102, no. 5: 1386-1403.

Connerton, Paul. 2008. "Seven Types of Forgetting." Memory Studies 1, no. 1: 59-71.

- 2009. How Modernity Forgets. Cambridge, UK: Cambridge University Press.

Dahan Kalev, Henriette. 1999. "Identity, Memory and Ethnicity: The Relation between Memory, Identity, Justice, Pluralism and Civil Rights." In Between "I" and "We"-The Construction of Identities and the Israeli Identity, edited by A. Bishara, 61-75. Jerusalem: Van Leer Jerusalem Institute and Hakibbutz Hameuchad Publishing House.

Davis, Rochelle. 2007. "Return to Half-Ruins: Memory, Postmemory, and Living History in Palestine." In Nakba: Palestine, 1948, and the Claims of Memory, edited by Ahmad H. Sa'di and Lila Abu-Lughod, 53-75. New York: Columbia University Press.

2011. Palestinian Villages Histories: Geographies of the Displaced. Stanford, CA: Stanford University Press.

Dobrin, Nurit. 2015. "Equal Opportunities in Education: Demographic and Socio-Economic Barriers." Central Bureau of Statistics, Chief Scientist Department Working Paper Series no. 19.

Dudai, Ron. 2017. "Transitional Justice as Social Control: Political Transitions, Human Rights Norms and the Reclassification of the Past." British Journal of Sociology 69, no. 3: 691-711.

- 2019. "Restraint, Reaction, and Penal Fantasies: Notes on the Death Penalty in Israel, 1967-2016." Law E Social Inquiry 43, no. 3: 862-88.

Durkheim, Émile. (1912) 1995. The Elementary Forms of the Religious Life. New York: Free Press.

Edelman, M. 1985. The Symbolic Uses of Politics. Chicago: University of Illinois Press.

Filc, Dani. 2009. The Political Right in Israel: Different Faces of Jewish Populism. New York: Routledge.

Flapan, Simha. 1987. The Birth of Israel: Myths and Realities. New York: Pantheon Books.

Fronza, Emanuela. 2006. "The Punishment of Negationism: The Difficult Dialogue between Law and Memory." Vermont Law Review 30: 609-26.

Gabai, Zvi. 2014. "The Day after November 29." Haartez, November 30 (in Hebrew).

—. 2015. "And What About Our Nakba?" Haartez, May 13 (in Hebrew).

—. 2017. "November 30th—Jewish Nakba Day." Haartez, November 29 (in Hebrew).

Galili, Amaya. 2009. "Nakba: Not a Dirty Word." Ynet, April 29.

Gellner, Ernest. 1983. Nations and Nationalism. Ithaca, NY: Cornell University Press.

Glickman, Aviad. 2009. "Ministers to Review Revised 'Nakba Law."' Ynet, July 18.

Gusfield, J. 1986. Symbolic Crusade: Status Politics and the American Temperance Movement. Chicago: University of Illinois Press.

Gutman, Yifat. 2016. "Memory Laws: An Escalation in Minority Exclusion or a Testimony to the Limits of State Power?" Law $\mathcal{G}$ Society Review 50, no. 3: 575-607.

. 2017. Memory Activism: Reimagining the Past for the Future in Israel-Palestine. Nashville, TN: Vanderbilt University Press.

— 2019. "A Declaration of Memory War: The Symbolic Effect of Illiberal Memory Laws in a Comparative Perspective." Mémoires en jeu/Memories at Stake 9: 72-76.

Halbwachs, Maurice. (1925) 1992. On Collective Memory. Chicago: University of Chicago Press.

Hartman, Ben. 2011. "Nakba Law' Passes Vote in Knesset Committee." Jerusalem Post, March 15.

Hill, Tom. 2005. "Historicity and the Nakba Commemorations of 1998." European University Institute Working Papers no. 2005/33, Robert Schuman Centre for Advanced Studies, Florence, Italy. 
Hsieh, Hsiu-Fang, and Sarah E. Shannon. 2005. "Three Approaches to Qualitative Content Analysis." Qualitative Health Research 15, no. 9: 1277-88.

Innes, Martin. 2003. Understanding Social Control: Deviance, Crime and Social Order. Maidenhead, UK: Open University Press.

Israel Hayom, 2014. "Netanyahu Didn't Address the Issue in Later Ceremonies." December 1.

—, 2015. "The Government and the UN Will Discuss the Deportation of Jews from Arab Lands and Iran." November 29.

Jamal, Amal, and Samah Bsoul. 2014. The Palestinian Nakba in the Israeli Public Sphere: Formations of Denial and Responsibility. Nazareth, Israel: I'lam Media Center for Arab Palestinians in Israel (in Hebrew).

Kadman, Noga. 2008. Erased from Space and Consciousness. Jerusalem: November Books (in Hebrew).

Khalidi, Walid. 1992. All That Remains: The Palestinian Villages Occupied and Depopulated by Israel in 1948. Washington, DC: Institute for Palestine Studies.

Khazzoom, Aziza. 1999. "Western Culture, 'Stigma' and Social Closure: The Origins of Ethnic Inequality among Jews in Israel." Israeli Sociology 2: 385-428.

Kimmerling, Baruch. 1983. Zionism and Territory: The Socio-Territorial Dimensions of Zionist Politics. Berkeley, CA: University of California Press.

2001. The End of Ashkenazi Hegemony. Jerusalem: Keter Publishing House (in Hebrew).

Kizel, Arie. 2014. The New Mizrachi Narrative in Israel. Tel Aviv: Resling (in Hebrew).

Kondracki, Nancy L., Nancy S. Wellman, and Daniel R. Amundson. 2002. "Content Analysis: Review of Methods and Their Applications in Nutrition Education." Journal of Nutrition Education and Behavior 34, no. 4: 224-30.

Koposov, Nikolay. 2017. Memory Laws, Memory Wars: The Politics of the Past in Europe and Russia. Cambridge, UK: Cambridge University Press.

Kremnitzer, Mordechai, and Roy Konfino. 2009. "Implications of the 'Nakba Law' on Israeli Democracy." Israel Democracy Institute, June 22.

Lemarchand, René, ed. 2011. Forgotten Genocides: Oblivion, Denial, and Memory. Philadelphia: University of Pennsylvania Press.

Liphshiz, Cnaan. 2018. "Poland's Prime Minister Said Some Jews Collaborated with Nazis. Scholars Say He Distorted History. Jewish Telegraphic Agency, February 20. https://www.jta.org/2018/ 02/20/news-opinion/world/scholars-say-polish-prime-minister-distorted-the-truth-about-jewishholocaust-collaborators.

Lis, Yoav. 2011. "Israel Prize Laureates: The Nakba Law Crashes the Principle of Separation of Powers, Tramples Freedom of Expression." Haaretz, February 28.

Löytömäki, Stiina. 2013. "The Law and Collective Memory of Colonialism: France and the Case of 'Belated' Transitional Justice." International Journal of Transitional Justice 7: 205-23.

Lubin, Alex. 2016. "Black Panther Palestine." Studies in American Jewish Literature 35, no. 1: 77-97.

Masalha, Nur, ed. 2005. Catastrophe Remembered: Palestine, Israel and the Internal Refugees. London: Zed Books

MFA (Ministry of Foreign Affairs). 2014. "Final Approval: The Exit and Deportation of Jews from Arab Lands and Iran Day," press release. Ministry of Foreign Affairs, June 24.

Minow, Martha. 2002. Breaking the Cycles of Hatred: Memory, Law and Repair. Princeton, NJ: Princeton University Press.

Morris, Benny. 1987. The Birth of the Palestinian Refugee Problem, 1947-1949. Cambridge, UK: Cambridge University Press.

. 1988. "The New Historiography: Israel Confronts its Past." Tikkun 3, no. 6: 19-23, 99-102.

. 1990. "The Eel and History: A Reply to Shabtai Teveth." Tikkun 5, no. 1: 19-22, 79-86.

—. 2007. "The New Historiography." In Making Israel, edited by Benny Morris, 11-28. Ann Arbor: University of Michigan Press.

Moses, Dirk A. 2011. "Genocide and the Terror of History." Parallax 17, no. 4: 90-108.

Nets-Zehngut, Rafi. 2011. "Origins of the Palestinian Refugee Problem: Changes in the Historical Hemory of Israelis/Jews 1949-2004.” Peace Review: A Journal of Social Justice 24, no. 2: 187-94.

Nyirubugara, Olivier. 2013. Complexities and Dangers of Remembering and Forgetting in Rwanda. Laden, Netherlands: Sidestone Press. 
Nora, Pierre. 1996. Realms of Memory. New York: Columbia University Press.

Olick, Jeffrey, and Joyce Robbins. 1998. "Social Memory Studies: From Collective Memory to the Historical Sociology of Mnemonic Practices." Annual Review of Sociology 1: 105-40.

Oren, Neta, and Daniel Bar-Tal. 2007. "The Detrimental Dynamics of Delegitimization in Intractable Conflicts: The Israeli-Palestinian Case." International Journal of Intercultural Relations 31, no. 1: $111-26$.

Pappe', Ilan. 1997a. "Post-Zionist Critique on Israel and the Palestinians: Part I: The Academic Debate." Journal of Palestine Studies 26, no. 2: 29-41.

. 1997b. "Post-Zionist Critique on Israel and the Palestinians: Part III: Popular Culture." Journal of Palestine Studies 26, no. 4: 60-69.

. 1998. "Fifty Years through the Eyes of 'New Historians' in Israel." Middle East Report 207: 14-23.

Peled, Yoav. 2014. The Challenge of Ethnic Democracy: The State and Minority Groups in Israel, Poland and Northern Ireland. New York: Routledge.

Ram, Uri. 1998. "Postnational Pasts: The Case of Israel." Social Science History 22, no. 4: 513-45.

- 2006. The Time of the Post. Tel Aviv: Resling (in Hebrew).

—. 2007. "The Future of the Past in Israel: A Sociology of Knowledge Approach." In Making Israel, edited by Benny Morris, 202-30. Ann Arbor: University of Michigan Press.

Ravid, Nadav. 2012. "National Security Council: Create a Link between the Palestinian Refugees and the Jews from Arab Countries." Haaretz, September 9 (on file with author).

Robinson, Shira. 2003. "Local Struggle, National Struggle: Palestinian Responses to the Kafr Qasim Massacre and Its Aftermath, 1956-66." International Journal of Middle East Studies 35, no, 3: 393-416.

Ronen, David. 2016. "The Supreme Court's Censored Freedom of Speech." In Conditional Citizenship: On Citizenship, Equality and Offensive Legislation, edited by Yousef T. Jabareen and Sarah OzackyLazar, 93-122. Haifa, Israel: Haifa University Press and Pardes Publishing House (in Hebrew).

Regev, David. 2010. "Left Property in Arab Countries? You Can Get It Back." Yediot Achronot, July 21.

Rieff, David. 2016. In Praise of Forgetting: Historical Memory and Its Ironies. New Haven, CT: Yale University Press.

Rowe, Shawn M., James V. Wertsch, and Tatyana Kosyaeva. 2002. "Linking Little Narratives to Big Ones: Narrative and Public Memory in History Museums." Culture Psychology 8, no. 96: 96-112.

Said, Edward. 2000. "Invention, Memory, and Place." Critical Inquiry 26, no. 2: 175-92.

Savelsberg, Joachim J., and Ryan D. King. 2005. "Institutionalizing Collective Memories of Hate: Law and Law Enforcement in Germany and the United States." American Journal of Sociology 111, no. 2: 579-616.

- 2011. American Memories: Atrocities and the Law. New York: Russell Sage Foundation.

Schejter, Amit M. 2007. "The Pillar of Fire by Night, to Shew Them Light': Israeli Broadcasting, the Supreme Court and the Zionist Narrative." Media, Culture and Society 29, no. 6: 916-33.

Schejter, Amit, and Moran Yemini. 2015. "A Time to Scatter Stones and a Time to Gather Them: Media and Telecommunications Ownership Trends in Israel 1984-2013.” Telecommunications Policy 39: 112-26.

Segev, Tom. 1993. The Seventh Million: The Israelis and the Holocaust. New York: Hill and Wang.

Shai, Aron. 2007. "The Fate of Abandoned Arab Villages in Israel 1965-1969." History and Memory 18, no. 2: 86-106.

Shalev, Meir. 2016. "We Too Are Miserable." Yediot Acharonot, September 9 (in Hebrew).

Shalom-Chetrit, Sami. 2004. The Mizrahi Struggle in Israel: Between Oppression and Liberation, Identification and Alternative, 1948-2003. Tel-Aviv: Am Oved (in Hebrew).

Shear, Michael B., and Maggie Haberman. 2017. "Trump Defends Initial Remarks on Charlottesville; Again Blames 'Both Sides."' New York Times, August 15.

Shenhav, Yehouda. 1999. "The Jews of Iraq, Zionist Ideology, and the Property of the Palestinian Refugees of 1948: An Anomaly of National Accounting." International Journal of Middle East Studies 31, no. 4: 605-30.

—. 2002. "Ethnicity and National Memory: The World Organization of Jews from Arab Countries (WOJAC) in the Context of the Palestinian National Struggle." British Journal of Middle Eastern Studies 29, no. 1: 27-56. 
—. 2003. "Hitching a Ride on the Magic Carpet." Haaretz, August 15.

Shafir Gershon. 1989. Land, Labour and the Origins of the Israeli-Palestinian Conflict, 1882-1914. Cambridge, MA: Cambridge University Press.

Shohat, Ella. 1999. "The Invention of the Mizrahim." Journal of Palestine Studies 29, no. 1: 5-20.

Shragai, Nadav. 2016. "Tunisia, The Day After." Israel Hayom, November 25.

Smooha, Sammy. 1993. "Class, Ethnic and National Cleavages and Democracy in Israel." In Israeli Democracy under Stress, edited by E. Sprinzak and L. Diamond, 309-42. Boulder, CO: Lynne Rienner.

- 2008. "The Mass Immigrations to Israel: A Comparison of the Failure of the Mizrahi Immigrants of the 1950s with the Success of the Russian Immigrants of the 1990s." Journal of Israeli History 27: 1-27.

2013. Still Playing by the Rules: Index of Arab-Jewish Relations in Israel 2012. Jerusalem: Israel Democracy Institute and University of Haifa Press (in Hebrew).

Shapira, Anita. 1998. "The Holocaust: Private Memory and Public Memory." In Independence: The First 50 Years, edited by A. Shapira, 527-40. Jerusalem: Zalman Shazar Center.

Shlaim, A. 1988. Collusion across the Jordan: King Abdullah, the Zionist Movement, and the Partition of Palestine. New York: Columbia University Press.

1995. "The Debate about 1948." International Journal of Middle East Studies 27: 287-304.

Slyomovics, Susan. 1998. The Object of Memory: Arab and Jew Narrate the Palestinian Village. Philadelphia: University of Pennsylvania Press.

Sofer, Ronni. 2011. "Nakba Law Approved: 'Thought Police in Israel." Yediot Achronot, March 23.

Swirski, Shlomo, Etty Konor-Atias, and Rotem Zelingher. 2015. "Israel: A Social Report 2015." Adva Center: Information on Equality and Social Justice in Israel. http://adva.org/wp-content/uploads/ 2016/03/social-2015-Eng.pdf.

Tirosh, Noam. 2016. "Reconsidering the 'Right to Be Forgotten': Memory Rights and the Right to Memory in the New Media Era." Media, Culture and Society 39, no. 5: 644-60.

Tirosh, Noam, and Amit Schejter. 2015. "I Will Perpetuate Your Memory through All Generations': Institutionalization of Collective Memory by Law in Israel." International Journal of Media and Cultural Politics 1, no. 1: 21-35.

Uladzislau Belavusau, and Aleksandra Gliszczyńska-Grabias, eds. 2017. Law and Memory: Towards Legal Governance of History. Cambridge, UK: Cambridge University Press.

Vinitzky-Seroussi, Vered. 2002. "Commemorating a Difficult Past: Yitzhak Rabin's Memorials." American Sociological Review 67, no. 1: 30-51.

Vinitzky-Seroussi, Vered, and Chana Teeger. 2010. "Unpacking the Unspoken: Silence in Collective Memory and Forgetting." Social Forces 88, no. 3: 1103-22.

Weiss, Yfaat. 2011. A Confiscated Memory: Wadi Salib and Haifa's Lost Heritage. New York: Columbia University Press.

Yemini, Ben-Dror. 2015. "Hush Money." Yediot Achronot, December 4.

Zertal, Idith. 2005. Israel's Holocaust and the Politics of Nationhood. New York: Cambridge University Press.

Zerubavel, Eviatar. 2003. Time Maps: Collective Memory and the Social Shape of the Past. Chicago: University of Chicago Press. . 2006. The Elephant in the Room: Silence and Denial in Everyday Life. Oxford: Oxford University Press. 